\title{
Use of aeromagnetometric and orbital surveys in the structural characterization of greenstone belt terrain of the Crixás province - Goiás.
}

Kleyver Lenno da Paixão Ataide*, Mônica Giannoccaro Von Huelsen**, Claudinei Gouveia de Oliveira*, Henrique Llacer Roig*, Karla Munique da Silva Pereira*, Cláudia Domingues Teixeira*. "Institute of Geosciences, University of Brasília - UnB; ${ }^{* *}$ Seismological Observatory - OBSIS, University of Brasília.

Copyright 2019, SBGf - Sociedade Brasileira de Geofísica

This paper was prepared for presentation during the $16^{\text {th }}$ International Congress of the Brazilian Geophysical Society held in Rio de Janeiro, Brazil, 19-22 August 2019.

Contents of this paper were reviewed by the Technical Committee of the $16^{\text {th }}$ International Congress of the Brazilian Geophysical Society and do not necessarily represent any position of the SBGf, its officers or members. Electronic reproduction or storage of any part of this paper for commercial purposes without the written consent of the Brazilian Geophysical Society is prohibited.

\section{Abstract}

Through the use of aeromagnetometric and orbital data in the region of the greenstone belts it was possible to better detail the diverse structural features present, as well as a better understanding of the geological evolution of the area. Orbital data from the PRISM sensor, from the ALOS satellite, as well as the digital elevation model (DEM) were used for this analysis. The result obtained with this information integration made possible a better understanding of the geological-structural behavior of the studied area, as well as of the mineralizations, allowing, among other things, an advance in the cartographic detail of the region.

\section{Introduction}

The Archaean Greenstone Belts of Goiás, which make up the Crixás mineral province, are located in the Tocantins Province in the central portion of Brazil, northwest of the Goiás massif (figure 1). The geological context present in these associations responsible for a large part of mineral deposits around the world, such as: silver, copper, nickel, chromium, zinc and gold. In the Goiás State, these terrains are belonging to the Crixás gold province (Guarinos, Pilar de Goiás, Faina and Crixás). They have great structural complexity, marked by ductile and and ruptile large-scale structures.

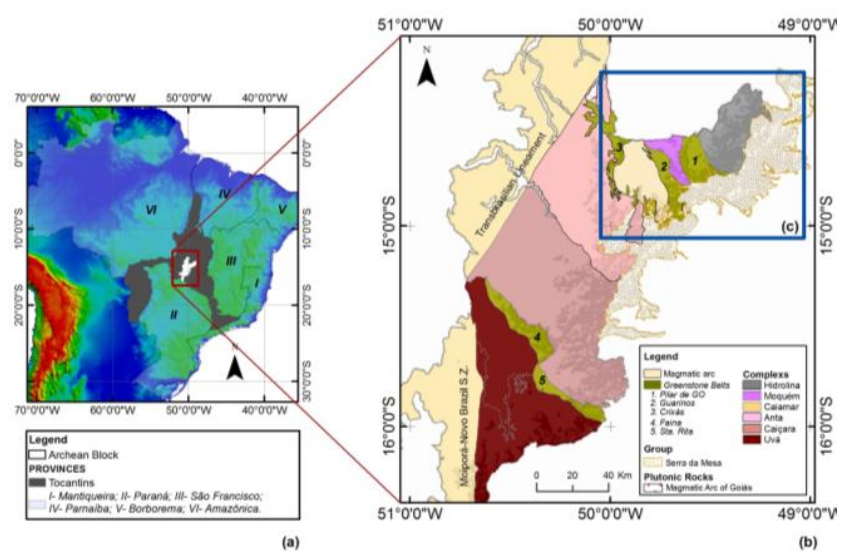

Figure 1. Geological location map of the studied area: (a) Tocantins Province, (b) Goiás Archaean Block and (c) simplified Geological map of the Crixás mineral province.
The Greenstone belts are separated by four orthogneisses complexes, such as Hidrolina, Moquem, Caiamar and Anta. The contact with the Moquém Block occurs through a thrust fault (Jost et al., 1994, 1995), which progresses from south to north, from front to side ramp, returning to the north end, to the Mandinopolis Shear Zone. Previous studies by Queiroz (2000), the structures in the Crixás, Guarinos and Pilar de Goiás Granite-greenstone belts and in the Anta, Caiamar, Hidrolina and the Moquém Block Complexes characterize five deformation phases, such as: $D_{n-3}\left(1^{\text {st }}\right.$ phase $) ; D_{n}$ 2 ( $2^{\text {nd }}$ phase $) ; \quad$ Dn-1 ( $3^{\text {rd }}$ phase $) ; \quad$ Dn $\left(4^{\text {th }}\right.$ phase $)$ and $\mathrm{Dn}_{+1}\left(5^{\text {th }}\right.$ and last phase). Being the $1^{\text {st }}$ and $2^{\text {nd }}$ Archaean phase, the first being responsible for the main tectonometamorphic foliation $\mathrm{S}_{\mathrm{n}-3}$; and the second comprises the polydiapical rise of the granitoids generating domes-andkeels and gneissification of some bodies (ca. 2.7 Ga). The third deformational phase, Paleoproterozoic, generated transport of younger supracrustals over the Archaean substratum, with main vergence to the north, and progressed from tangential to directional movements: The $4^{\text {th }}$ deformation phase, Neoproterozoic, is characterized by a tangential transport from NW to SE, towards the São Francisco Craton, and evolved to a directional regime attributed to the last deformation phase. Are assigned shear zones in the last deformation phase.

The lithology consists of succession of ultrabasic, basic rocks (metabasalts and amphibolites) and layers of metasedimentary rocks. It is bounded to the north with Proterozoic rocks by means of the Mandinopolis Shear Zone; to the east and west is limited, respectively, by the Moquém Block and Caiamar Complex; and to the south by the metallations of the Araxá Group (Jost et al., 2001).

The Archaean supracrustal occur in an extension of $40 \mathrm{~km}$ in direction $\mathrm{N} 10^{\circ}-20^{\circ} \mathrm{W}$, being limited with gneiss of the Moquém block by fault, to the west, with Neoroterozoic rocks by the Mandinópolis shear zone, to the north, and with the Hidrolina complex, the east. In the southern part, Paleoproterozoic metassedimentary rocks of Serra da Mesa Group cover them. The supracrustal rocks of this range were classified by Jost \& Oliveira (1991) in the Pilar Group of Goiás and are composed of metakomatites, metabasalts, rocks of sedimentary chemical origin and metapelites.

The Guarinos greenstone belt has four units that, from base to top, comprise: ritimites associated with basic tholeitic volcanism (São Patricinho Formation, iron formations SedEx deposits type (Aimbé Formation), 
biogenic phyllite (Cabaçal Formation - lower member) and ritimites - superior member) (Jost et al., 1995).

\section{Method}

Were used Aeromagnetometric surveys of the "Aerogeophysical Survey project of the State of Goiás, 2004 and 2006", carried out by the company LASA Engenharia e Prospecções, with a cartographic cut in the scale of 1: 25.000, with the following technical specifications: direction (FL): NS; Spacing (FL): $0.5 \mathrm{~km}$; Direction of control lines: $\mathrm{E}-\mathrm{W}$; spacing $(\mathrm{CL})$ : $5 \mathrm{~km}$; range (AM) $0.1 \mathrm{~s}$ (magnetometry) and flight height: $100 \mathrm{~m}$.

In the gold prospecting, these data are indirectly used to identify structures that may be associated with mineralization, as well as to detect the presence or absence of magnetic minerals associated with hydrothermalism (CARVALHO, 1999).

An evaluation of flight lines and consistency tests with the Fourth Difference presented by Blum (1999) was carried out and allowed the analysis of possible values outside the standard deviation of the data. The study area, because it was inserted between two different aerolevantings, it was necessary to use grinding suture using the meshes of the two areas. Subsequently, a micro-leveling was applied to the meshes in order to reduce the noise present. Was applied the micro-level proposed by Blum (1999) based on Minty (1991), which consists of (i) applying a high-pass filter on a grid-A in the direction perpendicular to the line of the flight, saving the result in a grid-B; (ii) applying a low-pass filter on the grid$B$, in the direction of the flight line, saving in the grid-C; (iii), and finally subtract the grid-A from the grid-C to obtain the final grid. After the microlevelling process, hanning type filtration was used. The data were interpolated using the minimum curvature method with a regular mesh of $125 \mathrm{~m}, 1 / 4$ of the spacing of the flight lines.

From the anomalous magnetic field, the Horizontal Derivatives (Dx and Dy) and Vertical Derivatives (Dz) of the $1^{\text {st }}$ order were generated. As well as the Total Horizontal Gradient Amplitude (HGA) of the horizontal derivatives; and the Analytical Signal Amplitude (ASA) of the horizontal and vertical derivatives.

In the Euler deconvolution, structural indices with values of 0 and 1 were used to obtain both the geological contacts and the linear features, respectively. This deconvolution deals with an automatic interpretation method that provides an estimate of the horizontal position and depth of anomalous sources from potential field data. For the calculation of the depth of the bodies, tolerances of 5,7 and $10 \%$ were used.

\section{Airborne Magnetometry}

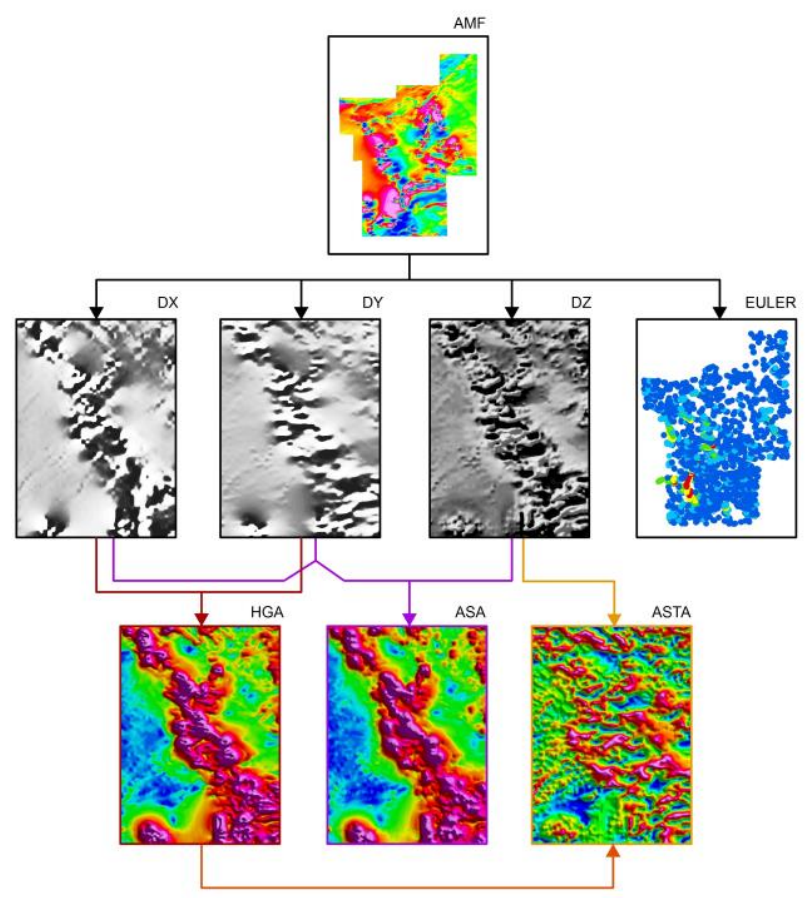

Figura 2. Flowchart of aeromagnetometric data processing. Anomalous magnetic field (nT=nanoTesla); Dx and Dy - first horizontal derivate (nT/m); Dz - first anomalous magnetic field vertical derivative (nT/m); HGA - total horizontal gradient amplitude (nT/m); ASA analytic signal amplitude $(\mathrm{nT} / \mathrm{m})$; and ASTA - analytic signal of tilt angle.

From the orbital data, the PRISM sensor of the ALOS satellite was used to obtain the detail of the tectonostructural features by means of a stereoscopic image of the study area. With a spatial resolution of $2.5 \mathrm{~m}$ at nadir and 1 band pancromatic. It is able to acquire images to generate digital surface models (MDS) in great detail, since it has three independent optical systems for visualization with nadir, forward and backward, producing images in stereoscopy along the orbit. Data from the digital terrain elevation model (DTM) with 16-bit radiometric resolution (range of 65,535 possible values to represent the altitude variable) and the original spatial resolution of 1 arc sec $(\sim 30 \mathrm{~m})$ were also used. From this data, a 3D perspective model was generated from which it was possible to extract information with good precision, such as: drainage network and structural lineaments.

The interpretative method used in the work was the systematic one, according to Soares and Fiori (1976) and, later, Cardoso de Lima (1995).

In the DEM, color slicing was used to represent altimetric intervals in different shades, in order to highlight more subtle topographic differences. In this step, adaptive median convolution filters were applied for smoothing and removal of imperfections; high-pass filter of artificial directional lighting, with variation of azimuth angles and elevation of illumination; and, finally, linear adjustment of histograms (Crosta, 1992). This technique emphasized the photo-interpretative attributes of interest, in view of 
the recognition of morphological features in the surface image. Figure 3.
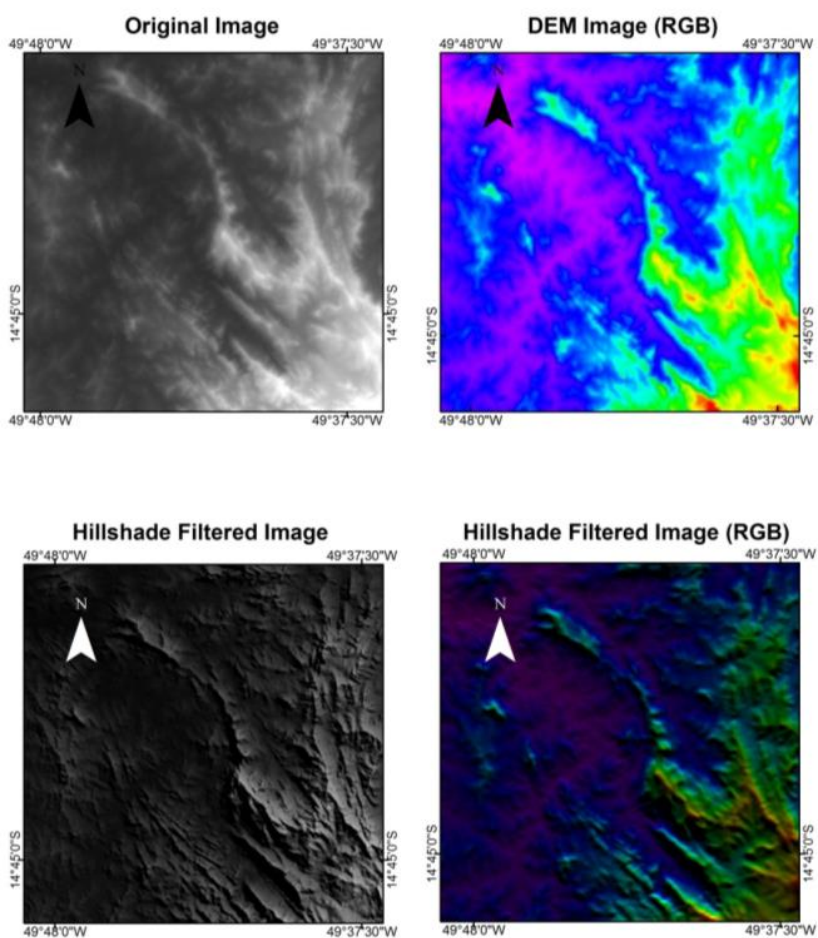

Figura 3. Data processing of DEM - SRTM

\section{Results}

The Euler result showed that the structures of index 1 (figure 4), corresponding to the dikes and / or sill, of the area are predominantly shallow with depths around 164 $882 \mathrm{~m}$, and are well marked, mainly in the south and north portion where proterozoic events occur. The structures extracted by $\mathrm{Dz}$ and by orbital image, are precisely corresponding to the information obtained by Euler, such as parts of Carroça, Engenho Velho, João Leite, Ribeirão das Antas / Rio Vermelho, Três Buracos and Mandinópolis shear zones.

The main geological structures are directly influenced by the Ribeirão das Antas / Rio Vermelho transpressive corridor. The contacts between the units are also very visible, such as Águas Claras granodiorite, belonging to Caiamar Complex, with Unit B composed of metapsamitic-pelitic of Serra da Mesa Group in which depths ranging from $464 \mathrm{~m}$ to $1.2000 \mathrm{~m}$, occasionally there are sites deeper with $1,360 \mathrm{~m}$. b) Crixás - Açu Gneiss with Tocambira Tonalite, both in the Caiamar. In relation to the magnetic field, the main gold occurrences are present in regions where the magnetic field varies from very high-tohigh.

The results obtained by aeromagnetometry, efficiently demarcate the main transcurrent shear zones of the study area, such as: Carroça, with continuous trend NW-SE delimiting the Guarinos greentsone belt and Moquém block, João Leite with the trend NNW-SSE delimiting the Pilar de Goiás greenstone belt with the Hidrolina Complex, and Três buracos that occurs in Pilar de Goiás greenstone belt.

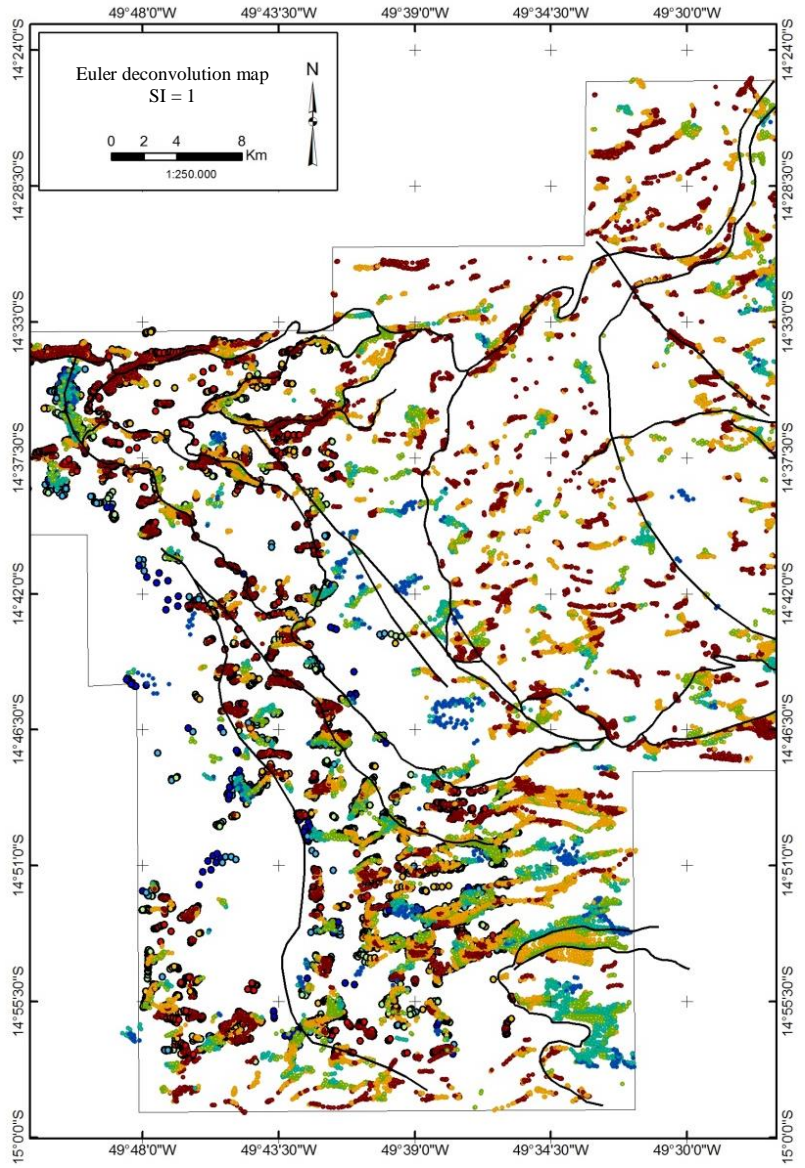

Figure 4. Euler deconvolution with structural index equal to 1.0 , tolerance 7 and window 10 .

The granitic complexes represented by Caiamar, Hidrolina and Moquém have some important structural variations; the first having direction WNW-ESSE, NNE and secondary ENE-WSW; the second has WNW-ESSE and the third has ENE-WSW. The NNE / SSW directions present in Caiamar and Hidrolina complexes are parallel to the Transbrasilian system. The extracted linear structures corresponding to the magnetic lineaments were superimposed on the PRISM image to obtain a greater detail of the structures.

By means of the remote sensing data it is possible to identify ductile, ductile-ruptile and ruptile structures, unlike magnetometric data that tend to emphasize structures as long as they have a magnetic character. Figure 5.

Rosettes diagrams were made to statistically quantify structural lineaments measures obtained through airborne geophysical images and orbital data in order to identify their structural direction. The azimuth rosettes show more clearly the existence of a structural complexity of the Guarinos's area and Pilar de Goiás, fact observed in guidelines with very varied orientations (figure 6). Similarly, the structures interpreted in the ALOS sensor image, superimposed on the AGHT, ASA, Dz and ISA products, highlight the structural patterns mentioned. These structural features were also well delimited in the digital elevation model. 


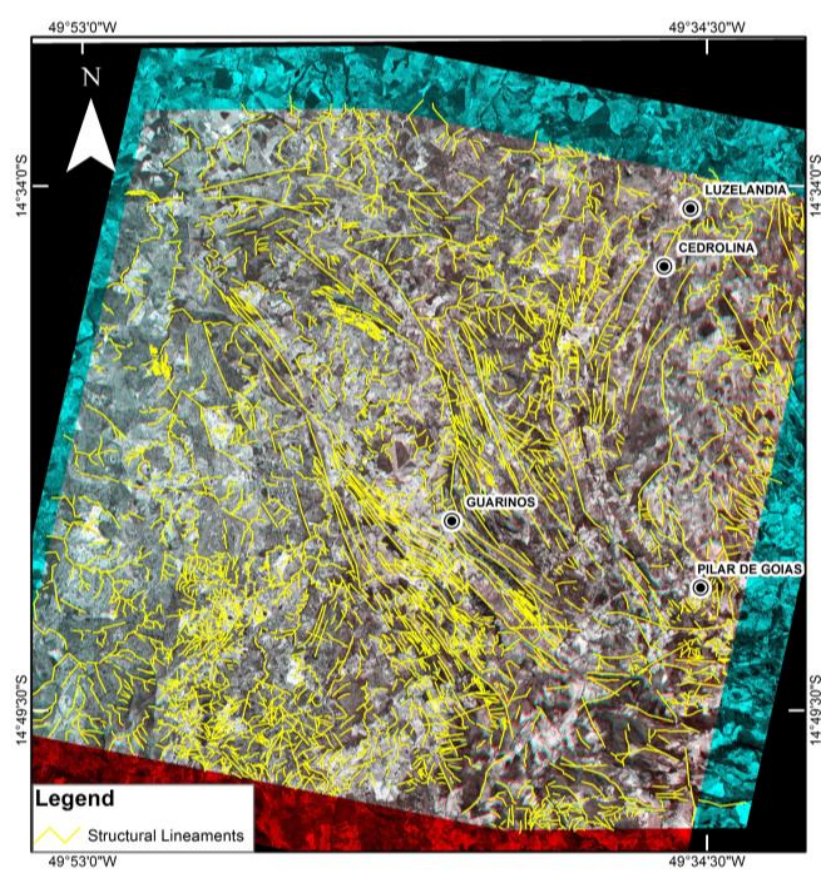

Figura 5. Structural lineaments extracted over the ALOS image.

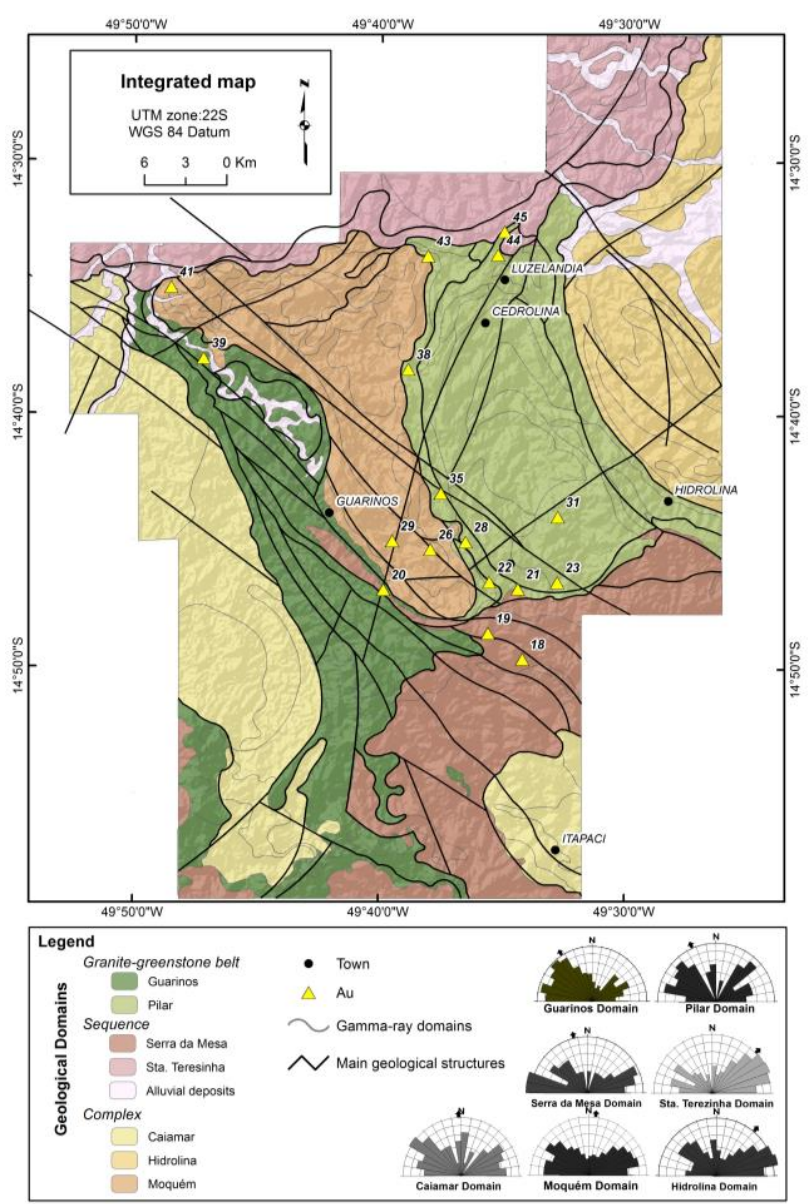

Figura 6. Structural domain map demonstrating the different orientations preferences of tectonic forces. Gold deposits, Guarinos: Maria Lázara (20), Caiamar (39); Serra da Mesa: Joaquim Isidoro (18), Carlão (19); Moquém: Natal (26), garimpo do Jair (29), José Candido (41); Pilar: Pilar de Goiás (31 e 23), Vanderlino (21), cachoeira do Ogó (22), Toti - Três buracos (28), Faz. Moinho (35), Morro do Tenente (38), Morro da Cacunda (43), Luzelândia (44 e 45).

\section{Conclusions}

The methodology used showed an excellent result that helps to better understand the tectono-structural context of the region Crixás granite-greenstone belts mineral province. By means of the integrated final product it was possible to delimit more accurately the main strutures ruptile, ductile and ruptile-ductile in mega-scale, as well as the textural features of the reliefs and drainage;

The applied orbital images helped to understand the topographic characteristics allowing a better analysis of the structures and assisting in the delimitation of the geological units. The use of stereoscopic imaging allowed an overview of the entire area in multiple scales up to 1: 20,000 . Because it does not have cloud obstruction, the use of radar images allows its application to be applied at different wavelengths, where it allows us to discriminate certain structural characteristics.

The remote sensing images, have demonstrated excellent indicative of geological structures, are ductile, ruptileductile and ruptile, unlike magnetometric image that highlight only those structures that have a magnetic character. The results obtained by the interpretation of structural lineaments in the PRISM / ALOS images more precisely delineated the main transcurrent shear zones on the Guarinos greenstone belt.

Through aeromagnetometry, it was possible to observe important structural features present in the area, such as a possible extension of carroça shear zones (Guarinos), where the occurrences of the Maria Lázara and engenho velho (Pilar de Goiás) are present the trend mineralized JOT, under the Serra da Mesa Group. But this feature is not very clear using Euler's deconvolution.

\section{Acknowledgments}

- Institute of Geosciences at University of Brasília UnB;

- National Council for Scientific and Technological Development (CNPq);

- mining company Yamana Gold Inc.

- Professor Raul Minas Kuyumjian, Hardy Jost and all the other reviewers, whose criticisms have contributed to the improvement of the final quality of the work.

\section{References}

BLUM, M.L.B. Processamento e interpretação de dados de geofísica aérea no Brasil Central e sua aplicação à 
geologia regional e à prospecção mineral. Brasília, Tese de Doutorado, Instituto de Geociências, Universidade de Brasília, 1999, 229p.

Crósta, A.P. Processamento digital de imagens de sensoriamento remoto. ed. rev. - Campinas, SP: IG/UNICAMP,1992. 170p

CARDOSO DE LIMA, M. I. Introdução à Interpretação Radargeológica. Rio de Janeiro: IBGE. 124 p., 1995.

CARVALHO, M. T. N. Integração de dados geológicos, geofísicos e geoquímicos aplicada à prospecção de ouro nos Greenstones Belts de Pilar de Goiás e Guarinos, GO. Instituto de Geociências, dissertação de mestrado, UnB, Brasília, 1999, $190 \mathrm{p}$.

JOST, H. \& OLIVEIRA A.M. Stratigraphy of the greenstone belts, Crixás Region, Goiás, central Brazil. Journal of South American Earth Sciences, 4(3): p. 201 214, 1991.

JOST H., CARMELO, A.C., MENESES, P.R. Litologias, relações de contato e estrutura do Bloco Caiamar, Crixás, Goiás. In. IV Simpósio de Geologia do Centro-Oeste. Anais. SBG. p. 18-20, 1994.

JOST, H.; KUYUMJIAN, R.M.; FREITAS, A.L.S.; et al. Geologia da Porção Norte do Greenstone belt de Guarinos, Goiás. In: Rev. Bras. De Geoc. V. 25, n.1, p. 51-60, 1995.

JOST, H; FIGUEIREDO; A. M. G.; FERREIRA, A.V. Elementos em traço e a proveniência clástica na transição de ambiente euxênico para turbidítico em metassedimentos do Greenstone belt de Guarinos, Goiás. In: V Congresso Brasileiro de Geoquímica. Niterói. Anais em CD-ROM, 1995.

JOST, H.; FORTES, P.T.F.O. Gold deposits and occurrences of the Crixás Goldfield, central Brazil. Mineralium Deposit, 36: p. 358-376, 2001.

JOST, H.; FUCK, R.A.; BROD, J.A.; et al. Geologia de terrenos Arqueanos e Proterozóicos da região de Crixás - Cedrolina, Goiás. Revista Brasileira de Geociências, 31 (3). p. 315-328, 2001.

MINTY, B.R.S. Simple micro-leveling for aeromagnetic data. Exploration Geophysics, 22: p. 591-592, 1991.

QUEIROZ, C.L. Evolução tectono-estrutural dos terrenos granito-greenstone belt de Crixás, Brasil Central. Tese de Doutorado, Instituto de Geociências, Universidade de Brasília, 2000, 209 p.

SOARES, P. C.; FIORI, A. P. Lógica e sistemática na análise e interpretação de fotografias aéreas em geologia. Noticiário geomorfológico, [S.I.], v.16, n. 32, p. 107- 121, 1976. 